\title{
A Few Times a Month
}

National Cancer Institute

\section{Source}

National Cancer Institute. A Few Times a Month. NCI Thesaurus. Code C159852.

Happening a few times during a month. 